\title{
Transaction Costs in Constructing Small and Medium Hydro Power Plants in Albania
}

\author{
By Florian Miti ${ }^{1}$, Grigor Dede ${ }^{2}$
}

\begin{abstract}
Identifying the transaction costs helps knowing which are the real costs of starting a new business, finding bottlenecks, can serve to reduce inefficiencies and encourage more effective reforms. In this article we analyze the impact of transaction costs in interactions between firms and public authority, when firms participate in the bidding procedure for constructing new hydropower plants until the stage of producing electricity. In the first years, after granting the concession right, firms face many difficulties due to a complex normative regulation, contractual conditions and bureaucracy. Although in the majority of the cases, winning firms are provided by the public authority with the concessionary permit within the legal deadlines, they fail to start producing electricity within the declared timetable. Even though direct transaction costs computed by measuring the actual costs that firms or individuals face during these procedures may be relatively low, fairly $1-2 \%$ of the total cost of investment, opportunity costs considering the potential loss in the revenues due to delays in producing and selling electricity, in some cases, can be equal to the total cost of constructing the implant.
\end{abstract}

Keywords: transaction costs, concessions, hydro power constructing, regulation.

\section{Introduction}

A good economic performance of a firm depends also on low transaction costs. Transaction costs take various forms and yet there is not an universally wide-accepted theoretical definition. In this paper we try to define and estimate transaction costs in interactions between firms and the public authority, while firms participate in the bidding procedure for constructing new hydropower plants until the stage of producing electricity in a concessionary regime. The following section, deals with the multiple nature of transaction costs and the vast theoretical contributions to Transaction Costs Economics. In the third section, facts and data are used to describe the energy sector. In the fourth section, costs and procedures of granting the concessionary right of the bidding firms are presented to describe the regulatory framework and the complexity of this initiative that the entrepreneurs face. Section five considers findings and results stating that delays in starting producing electricity seem not to be connected with the cost of investment or with the size of the power installed to produce electricity. Another finding is that in many cases of new hydropower plants, the potential loss of revenues due to delays in production, equals the investment costs estimated for constructing the hydropower plant. Conclusions follow.

\section{Theoretical Bases}

The nature of transaction costs is so complex and various in the forms that this appears in numerous theoretical definitions of transaction costs used in the economics literature. Transaction costs can be identified initially in Coase's (1937, p. 9) formulation as "the cost

2 Department of Finance, University "Ismail Qemali” of Vlora, Albania. 
involved in the carrying out the transaction in the open market". According to Williamson (1981, p. 552), "Transaction cost analysis concerns about the comparative costs of planning, adapting, and monitoring task completion under alternative governance structures". He argues that transaction costs are determined by the following elements: uncertainty, frequency, specificity, limited rationality and opportunistic behaviour of the agents (Williamson 1979 and 1981).

A more recent formulation of the transaction costs can be adopted by the definition used by Furubotn and Richter (1997, p. 40) where "transaction costs include the costs of resources utilized for the creation, maintenance, use, change, and so on of institutions and organizations" while in the case of the existence of property and contract rights, the authors include in the transaction costs "the costs of defining and measuring resources or claims, plus the costs of utilizing and enforcing the rights specified". While Coase provides a link between transaction costs and property rights stating that "in the absence of transaction costs, the allocation of resources is independent of the distribution of property rights", Furubotn and Richter, in a situation of transferring the existing property rights and in establishing or transferring contract rights between individuals, include in the transaction costs, the costs of information, negotiation, and enforcement.

In principle, we could identify three aspects of transaction costs:

i) The cost of participating in the market, originally discussed in the seminal paper of Coase (1937), where the "price mechanism" plays a role in the firm's "make" or "buy" decisions.

ii) Internal managing costs of corporate governance, focusing on the principal-agent problem and property rights (Jensen \& Meckling (1976), Johnsen (1993), Bulter, (1989), Fama E. F. \& Jensen M. C. (1983), Allen, (1999 and 2000), Alchian and Demsetz (1972), Williamson (1971, 1985).

iii) The cost of interaction with Public Institutions, that the costs that the firm has to bear in order to fulfil the Public Institution obligations and are the focus of this article.

Many empirical analysis of transaction costs have been made in the case of vertical integrated firms finding that asset specificity and uncertainty have significant effect on the structure of production (Williamson (1983), Shelanski and Klein (1995). When full integration does not occur, long- term contracts and other complex contracts with reciprocity are used to offset specific investment hold up problem. In the case of long-term contracts, important contributions bring the studies of Joskow (1985,1987,1988b and 1990); Crocker and Masten (1988); Goldberg and Ericson (1987); De Canio and Frech (1993); Pirrong (1993) resulting that the contracts tend to be more complete when the contractor has a history of disputes with purchasers and less complete when there is a high degree of intertemporal or technological uncertainty.

\section{Data and Methodology}

Benham and Benham (1998 and 2001), define the cost of exchange (between different individuals and countries), as the opportunity cost faced by an individual to obtain a specified good using a given form of exchange within a given institutional setting.

Specifically, the authors, define the "cost of exchange Cijkm as the opportunity cost in total resourcesmoney, time, and goods - for an individual with characteristics $i$, to obtain a good $j$, using a given form of exchange $k$, in institutional setting $m^{1}$ ". Therefore, the costs of exchange include both, the costs of production and transaction costs incurred by the individual in obtaining the good.

The authors explain that where transaction costs are very high, many transactions do not take place at all. Hence only a little part of all potential transactions actually occur, and of these, only a subset appear as market transactions.

Modifying the model for the HPP construction under concessionary regime:

${ }^{1}$ The form of exchange, like in De Soto (1989), it can happen in both, formal or informal market. 
$>$ The costs of exchange $=$ Production costs + Transaction costs

- Production costs = Investment value (Value of civil works + Machineries + line construction )

- Transaction Costs = Monetary ( Tariffs, fees, intermediaries etc.) + non Monetary (days of delays because of procedures and bureaucracies, regulations, etc.)

The focus of the analysis are the concessionary contracts of hydropower plants under implementation and underwritten after the entry in force of the Law No. 9663, dated 18.12.2006 "Law on concessions". According to the database published by the Albanian Ministry of Economy ${ }^{2}$, Trade and Energy, between the years 2007-2010, there were underwritten 98 concessionary contracts for the construction of $260 \mathrm{HPP}-\mathrm{s}$ and with a total power installed of nearly 1.2 million $\mathrm{kW}$.

In the end of 2013, the total number of HPP concessionary contracts was $132^{3}$ for the construction and rehabilitation of 384 hydropower plants, with a total power of $1.633 \mathrm{MW}$ and a total investment of 2.4 billion Euro. By the end of 2014, only 32 "successful" contracts had HPP already working and producing electricity.

Considering the 32 working hydropower plants, the variable under examination is the time lag between the predicted date of finished works and the actual date the plant was ready to use and start producing electricity. Any delay from the predicted date of starting functioning, would create a loss of revenues for not selling the product during this period, penalties from the Contracting Authority and since these companies operate in a concessionary regime, every delay would shorten their licensing period in disposal causing higher opportunity costs.

\section{Procedures and Costs}

The procedure of granting concessionary rights for exploiting the river basin starts with a formal request of the firm to exploit a part of a river by presenting a pre -feasibility study to prove that the project proposed is rentable. After the identification of the potential concession, the Contracting Authority starts the bidding selection procedure. Obviously, the expenses made to participate in the bidding procedures and feasibility studies are not refundable. Extra costs of publication are charged to the firm when the biding call for proposals is published in national and international newspapers. The qualified bidders or candidates are supposed to submit the bid security form with a value of $2 \%$ of the investment value of the project and a validity of 150 days. Statistics for 38 bidding procedures in 2007, show that in this preparatory phase, it takes in medium two months to organize the procedures for opening the bid's offers, starting from the publication date of the call for proposals.

The evaluating process of the projects submitted has different deadlines related to the size of the hydropower plant: 30 days for small ones, 60 for medium and 90 for big plants. The evaluating process proclaims the winner who is called afterwards to negotiate the concessionary contract. Using 78 observations related to procedures of evaluation, during 2007 - 2009, we get a mean period of 234 days and a standard deviation of 4 months, which is actually high considering the number of observations. This implicates that many bids are delayed in the evaluation phase because the evaluating commission needs additional time or because the evaluating process is stopped by other institutions like the Tribunal or by the Public Procurement Agency due to disputes between contending bidders.

Prior to the signing of the contract, the bidder who has been awarded the concession should submit an insurance contract worth up to $10 \%$ of the value of the project, if the installed power is less than $15 \mathrm{MW}, 7 \%$ if the installed power is between 15 and $30 \mathrm{MW}$ and $5 \%$ for projects where

2 www.mete.gov.al

3 Source: Gazeta Dita 24 July 2013. 
the installed power is higher than $30 \mathrm{MW}$, leading to further opportunity costs by freezing considerable financial capital.

\section{Results}

Considering the finished hydropower plants, the "delay" variable is tested against the "investment costs", "power in $\mathrm{kW}$ installed" and "estimated time of entry into service". Using a multiple linear regression analysis, we get the following results table:

Table 1.

\section{Coefficientsa}

\begin{tabular}{|l|c|c|c|c|c|}
\hline \multirow{2}{*}{ Model } & \multicolumn{2}{|c|}{ Unstandardized Coefficients } & Standardized Coefficients & \multirow{2}{*}{$\mathrm{t}$} & Sig. \\
\cline { 2 - 6 } & $\mathrm{B}$ & Std. Error & Beta & & 6,898 \\
\hline (Constant) & 3,303 &, 479 & &, 000 \\
Investment in ALL & $6,020 \mathrm{E}-010$ &, 000 &, 381 &, 840 &, 409 \\
Expected Time entry in service &,- 977 &, 266 &,- 618 & $-3,669$ &, 001 \\
Power in kW installed & $-1,297 \mathrm{E}-005$ &, 000 &,- 061 &,- 136 &, 893 \\
\hline
\end{tabular}

a. Dependent Variable: Delay Year

In Table 1, the Beta coefficients of the "Investment costs" and "Power in kW installed" variable are not significant since their respective $\mathrm{p}$-value is higher than 0.05 so these variables have no explanatory power and can be both zero.

The final result of this analysis is that delays seems not to be connected with the cost of investment or with the size of the power installed to produce electricity. The only significant variable is the "Expected time" of entry into service variable, which has a negative coefficient, showing that the dependent variable, "Delays", on average will decrease as the expected time estimated by the entrepreneur of entry in service of the implant increases.

Considering the singular delays for each investment, computed as the difference between the actual date of starting producing electricity and the estimated period of entry in production, and the yearly production of electricity of each plant during the year 2013, we can compute the potential loss in revenues for each concession. The following Figure 2, presents on the vertical axes the investment costs of constructing the hydro power plants in million Lek and the potential loss in revenues due to delays in million Lek while, the respective power of the hydropower plant in MW is on the horizontal axes. It is clear from this Figure that both lines follow a similar trend and in many cases, the potential loss of revenues, equals the investment of constructing the plant (the points where both lines intercept).

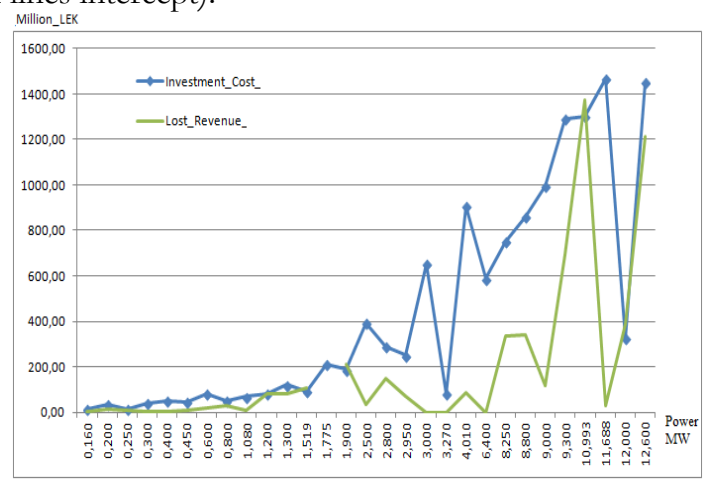

Figure 2. 
Note also that in this Figure we have presented small and medium hydro power plants (up to 12.6 MW) and that there are some missing points in the potential loss of the revenues due to missing data.

\section{Conclusions}

In this paper, the analysis is focused in a particular typology of transaction costs, the costs of interacting with public institutions of firms granting concessionary rights for constructing new hydropower plants in a regulated regime. Due to the specificity of these investments and different technology used, it is difficult to derive general conclusions, but all these investments have to meet the same legal obligations and follow the same procedures. While competing for the concession right, bidding firms face many transaction costs like: pre- feasibility studies, bidding security forms, notary costs and other fees of lawyer's assistance. The evaluation process might exceed the legal period of announcing the winner in some cases due to technical problems and legal disputes but in general concession's permits are granted within the legal terms. The contract negotiation process requires further conditions that the winning firm must meet, (e.g. the contract security form) adding other costs to this initiative. The monetary costs deriving from these procedures are considerable but still a little fraction (1-2\%) if compared to the total investment cost of constructing the hydropower plant.

Opportunity costs instead, arising when there are delays in constructing and thus in producing electricity, shortening the licensing period of the concession, can reach a considerable amount. In some cases, referring to Figure 2, they equal the entire investment. The final result of this analysis is that delays seems not to be connected with the cost of investment or with the size of the power installed to produce electricity. Delays in construction might come from legal disputes with other firms participating in the bidding process, temporary financial difficulties, regulation, bureaucracy, corruption, brokers, expropriation procedures and other factors difficult to be quantified or verified for each case.

Reducing transaction costs by reducing bureaucracy and tariffs, promoting the ease of doing business, avoiding bottlenecks and providing the firms with licenses and permits in less time, would affect positively the success of the new investments, a better allocation of the resources and would have a pro-growth impact on the county's economic perspective.

\section{References}

Alchian A. \& Demsetz H. (1972), "Production, Information Costs, and Economic Organization", The American Economic Review, vol. 62, pp. 777-795.

Allen D. W. (2000), “Transaction Costs”, in Boudewijn Bouckaert and Gerrit De Geest, eds., The Encyclopedia of Law and Economics, Chelthenham, Edward Elgar, pp. 893-926.

Benham A. \& Benham L. (2001), "The cost of Exchange", Roland Coase Institute Working Papers, No. 1.

Bulter H. (1989), "The Contractual Theory of the Corporation”, George Mason Law Review, vol. 11 No. 4, pp. 99-123.

Chen P. (2007), "Complexity of Transaction Costs and Evolution of Corporate Governance", The Kyoto Economic Review, vol. 76, No 2, pp. 139-153.

Clerico G., Novarese M., Rizzello S. (2007), "I Costi di Transazione: Analisi Teorica ed Indagine Empirica", Giuffrè Editore, Milano.

Coase R. H. (1937), “The Nature of the Firm”, Economica, vol. 4, pp. 386-405.

Coase R. H. (1960), "The Problem of Social Cost", Journal of Law and Economics, vol. 3, pp. 1-44.

Coase R. H. (1998), "The New Institutional Economics", American Economic Review, vol. 88, No.2, pp. $72-74$.

Coase R. H. \& Williams E. (1964), "Discussion", American Economic Association, vol. 54, No 3, pp. 192197.

Crocker K. J. \& Raynolds K. J. (1993), "The Efficiency of Incomplete Contracts: An Empirical Analysis of Air Force Engine Procurement", The RAND Journal of Economics, vol. 24, No. 1, pp. 126-146. 
Fama E. F. \& Jensen M.C. (1983), “Agency Problems and Residual Claims”, Journal of Law \& Economics, vol. 26, No. 2, pp. 327-349.

Furubotn G. E. And Richter R. (1997), "Institutions and economic theory: The contribution of the new institutional economics", Ann Arbor: University of Michigan Press.

Goel K. R. (2008) "Regulatory bottlenecks, transaction costs and corruption: A cross-country investigation ", Bank of Finland (BOFIT) Discussion papers.

Jensen M. C. \& Meckling W.H. (1976) "Theory of the Firm: Managerial Behavior, Agency Costs and Ownership Structure", The Journal Of Financial Economics, vol. 3, No 4, pp. 305-360.

Joskow P. (1985), "Vertical Integration and Long-term Contracts: The Case of Coal-burning Electric Generating Plants" Journal of Law, Economics \& Organization, vol. 1, No. 1, pp. 33-80.

Joskow P. L. (1987), "Contract Duration and Relationship-Specific Investments: Empirical Evidence from Coal Markets", American Economic Review, vol. 77, No. 1, pp. 168-185.

Joskow P. (1991), "Role of Transaction Cost Economics in Antitrust and Public Utility Regulatory Policies" Journal of Law, Economics \& Organization, vol. 7, Special issue, pp. 53-83.

Shelanski H. A. \& Klein P. G. (1995), "Empirical Research in Transaction Cost Economics: A Review and Assessment" Journal of Law, Economics \& Organization, vol. 11, No. 2, pp. 335-361.

Marquez M. (1990), "The Other Path by Hernando De Soto" Boston College Third World Journal, vol. 10, No. 1, pp. 204-213.

Ménard C. (ed) (2000), "Institutions, Contracts and Organizations: Perspectives from New Institutional Economics" Edward Elgar Publishing Limited, Cheltenham, UK.

Wang N. (2003), "Measuring Transaction Costs: An Incomplete Survey" The Roland Coase Institute Working Papers, No 2.

Williamson, O. E. (1971), "The Vertical Integration of Production: Market Failure Considerations", American Economic Review, vol. 61, No. 2, pp. 112-123.

Williamson O. E. (1976), "Franchise Bidding for Natural Monopolies-In General and with respect to CATV”, Bell Journal of Economics, vol. 7, No. 1, pp. 73-104.

Williamson O. E. (1979), "Transaction Cost Economics: The Governance of Contractual Relations", Journal of Law and Economics, vol. 22, No. 2, pp. 233-261.

Williamson O. E. (1998), “Transaction Cost Economics: How It Works; Where It Is Headed”, De Economist, vol. 146, No 1, pp. 23-58.

Williamson O. E.(2007), "Transaction Cost Economics: An Introduction." Economics Discussion Papers, No 2007-3, Kiel Institute for the World Economy. 